\title{
Diversity and plant growth promoting properties of rhizobia isolated from root nodules of Ononis arvensis
}

\author{
Sylwia Wdowiak-Wróbel • Monika Marek-Kozaczuk • Michał Kalita • \\ Magdalena Karaś • Magdalena Wójcik • Wanda Małek
}

Received: 28 October 2016/ Accepted: 28 April 2017/Published online: 12 May 2017

(C) The Author(s) 2017. This article is an open access publication

\begin{abstract}
This is the first report describing isolates from root nodules of Ononis arvensis (field restharrow). The aim of this investigation was to describe the diversity, phylogeny, and plant growth promoting features of microsymbionts of $O$. arvensis, i.e., a legume plant growing in different places of the southern part of Poland. Twenty-nine bacterial isolates were characterized in terms of their phenotypic properties, genome fingerprinting, and comparative analysis of their $16 \mathrm{~S}$ rRNA, nodC and acdS gene sequences. Based on the nodC and 16S rRNA gene phylogenies, the $O$. arvensis symbionts were grouped close to bacteria of the genera Rhizobium and Mesorhizobium, which formed monophyletic clusters. The acdS gene sequences of all the isolates tested exhibited the highest similarities to the corresponding gene sequences of genus Mesorhizobium strains. The presence of the $a c d S$ genes in the genomes of rhizobia specific for $O$. arvensis implies that these bacteria may promote the growth and development of their host plant in stress conditions. The isolated bacteria showed a high genomic diversity and, in the BOXPCR reaction, all of them (except three) exhibited DNA fingerprints specific only for them. Our studies
\end{abstract}

S. Wdowiak-Wróbel $(\bowtie) \cdot$ M. Marek-Kozaczuk ·

M. Kalita · M. Karaś · M. Wójcik · W. Małek

Department of Genetics and Microbiology, Maria Curie -

Skłodowska University, Akademicka 19 St.,

20-033 Lublin, Poland

e-mail: s.wdowiak@poczta.umcs.lublin.pl showed that restharrow isolates formed effective symbiotic interactions with their native host $(O$. arvensis) and Ononis spinosa but not with Trifolium repens and Medicago sativa belonging to the same tribe Trifolieae as Ononis species and not with Lotus corniculatus, representing the tribe Loteae.

Keywords Ononis arvensis $\cdot$ Phylogeny $\cdot$ Rhizobia · PGPB

\section{Introduction}

The family Fabaceae represents a large family of angiosperms. It includes about 750 genera and 19,000 plant species (Graham and Vance 2003; Weir et al. 2004). Within this family, the genus Ononis comprises about 70 species occurring in Europe, Asia, and Africa. In Poland, this genus is represented by three species, i.e., Ononis arvensis, Ononis spinosa, and Ononis repens. The latter two species are subject to partial protection in Poland. Plants belonging to Ononis genus are perennial herbs and shrubs. Many species of the genus Ononis are a source of therapeutic agents such as essential oils, flavonoid glycosides, and tannins. One of the representatives of this genus is $O$. arvensis $\mathrm{L}$. The ingredients of this plant are used in traditional folk medicine for the treatment of various diseases, e.g., those connected with bladder and kidney (Kirmizigul et al. 1997; Suntar et al. 2011; 
Gampe et al. 2016). Based on the potential value of the Ononis species, we decided to collect and characterize 29 strains associated with $O$. arvensis, using different approaches including phenotypic as well as genotypic characteristics for their potential use as PGPB.

Nitrogen is an essential element for the functioning of all living organisms. It is worth noting that nitrogen is also one of most potent plant-growth limiting nutrients (Greenwood 1982). The process of biological nitrogen fixation (BNF), providing nitrogen for soil fertility, is carried out by free-living soil microorganisms and by microorganisms forming symbiotic associations with higher plants. Rhizobial strains are able to form symbiosis with leguminous plants and to convert atmospheric $\mathrm{N}_{2}$ into ammonium $\left(\mathrm{NH}_{4}\right)$ in the process of nitrogen fixation, which takes place in special plant organs called root or stem nodules.

Rhizobia represent the group of Alphaproteobacteria and Betaproteobacteria. Already, many genera and species of these bacteria have been described. Alphaproteobacteria comprise microorganisms of the genera Rhizobium, Mesorhizobium, Ensifer, Azorhizobium, Bradyrhizobium, Methylobacterium, Devosia, Ochrobactrum, Phyllobacterium, Shinella, and Microvirga, while Betaproteobacteria are represented by bacteria of the genera Burkholderia and Cupriavidus (Wei et al. 2002; Ardley et al. 2012; Peix et al. 2015).

Different types of data are used, i.e., phenotypic, genomic, and phylogenetic, to determine the taxonomic position of bacteria. Phylogenetic studies allow determination of the taxonomic position of bacteria and show their relationship with other groups of microorganisms. Phenotypic analysis is used for preliminary classification of bacteria into the genus as well as identification and differentiation of bacteria based on their metabolic and physiological properties. It also facilitates selection of so-called plant growth promoting bacterial strains that may beneficially influence plant growth and development. For many years, the 16S rRNA gene has been commonly used as a molecular marker in defining the taxonomic position of new prokaryotic isolates. However, due to the high conservation of this molecule, it can be used to determine the genus position than that of the species.

Numerical analysis of phenotypic and genotypic features not only allows preliminary determination of the genus position of microorganisms but also facilitates selection of bacteria that have a positive impact on plant growth and development through different mechanisms such as siderophore production, auxin synthesis (indoleacetic acid-IAA), phosphate solubilization, and 1-aminocyclopropane-1-carboxylate (ACC) deaminase production (Hassan et al. 2015; Anwar et al. 2016). Such plant growth promoting rhizobacteria (PGPR) may be used as plant inocula to improve their development. PGPR include both freeliving microorganisms, including cyanobacteria, endophytes colonizing plant tissues, and bacteria that are able to establish symbiotic relationships with plants.

In the recent years, many studies on the diversity of rhizobia have been carried out and many new rhizobial species have been described, including those with plant growth promoting properties (PGPB). However, up to now, there have been no reports about $\mathrm{N}_{2}$ fixing microsymbionts of $O$. arvensis. This is the first paper concerning the metabolic, phenotypic, physiological, and plant promoting growth properties of $O$. arvensis nodule isolates, as well as genotypic characteristics, 16S rRNA gene and nodC sequence analysis, and the presence and phylogeny of $a c d S$ genes of these bacteria originating from south-eastern Poland. These studies will help us to identify strains effective in plant growth promotion, which are tolerant to stress conditions and they can be used in the future as a biofertilizer in agriculture.

\section{Materials and methods}

Strain isolation

Twenty-nine strains were isolated from root nodules of O. arvensis (a plant growing in south-eastern Poland) using a standard method described by Gnat et al. (2014). The $O$. arvensis plants were carefully uprooted, the rhizosphere soil was shaken off and roots were washed in sterile water to remove adhering soil. Healthy, pink, and firm nodules from legume roots were taken under consideration. The nodules were surface sterilized with $0.1 \% \mathrm{HgCl}_{2}$ (w/v) for $1 \mathrm{~min}, 95 \%$ ethanol (v/v) for $1 \mathrm{~min}$, then rinsed several times with sterile water. Suspension were made by crushing single nodules in a sterile petriplate containing a few drops of sterile normal saline. A loopful of suspension was streaked on yeast-mannitol medium (YEM) and incubated at $28^{\circ} \mathrm{C}$ for 3-5 days. Bacteria isolated from $O$. arvensis root nodules were 
purified by streaking several times on YEM agar (Gnat et al. 2014). The purified strains were kept in YEM medium at $4{ }^{\circ} \mathrm{C}$ as well as at $-20{ }^{\circ} \mathrm{C}$ in YEM medium with $20 \%$ (v/v) glycerol.

The ability of the studied strains to induce nodules on $O$. arvensis roots was confirmed by inoculation of plants with these bacteria.

The strains are in the collection bank of the Department of Genetics and Microbiology, Maria Curie-Skłodowska University.

\section{Phenotypic properties}

All strains used in this study are listed in Table 1 . The $O$. arvensis isolates were studied for the Gramstaining reaction, structure, colour of their colony (Gnat et al. 2014), and 126 other phenotypic features. All phenotypic tests were done in triplicate, at least twice.

BS agar medium (Sherwood 1970) with bromothymol blue $(0.0025 \%, \mathrm{w} / \mathrm{v})$ as a $\mathrm{pH}$ indicator was used to analyse the ability of $O$. arvensis microsymbionts to use different compounds as a sole carbon source. Mannitol present in the BS medium was replaced with one of the following compounds $(1 \%$, w/v): glucose, D-galactose, D-arabinose, D-mannose, D-fructose, Dxylose, D-cellobiose, D-raffinose, D-trehalose, L-arginine, L-lysine, L-alanine, L-asparagine, L-tyrosine, Lglutamine, L-histidine, L-threonine, L-rhamnose, dextrin, glycerol, lectin, salicin, sodium citrate, sodium hippurate, sodium tartrate, maltose, starch, sucrose, inulin, and Tween 20, used as a sole carbon source. YEM containing mannitol as a sole carbon source was used as a positive growth control and the medium without any carbon source served as a negative control.

To assess the utilization of various substrates as a sole nitrogen source, $\mathrm{NH}_{4} \mathrm{Cl}$, present in the $\mathrm{BS}$ medium was replaced with one of the following compounds $(1 \%, \mathrm{w} / \mathrm{v})$ : $\mathrm{NaNO}_{3}$, L-glutamine, L-tyrosine, L-threonine, L-leucine, DL-valine, L- phenylalanine, L-methionine, L-histidine, L-cysteine, DLisoleucine, L-lysine, L-alanine, L-aspartate, L-glutamate, L-serine, DL-ornithine, L-arginine, L-proline, and glycine.

Growth characteristics for $O$. arvensis nodule isolates was recorded at different temperatures $(4,6$, $\left.28,37,45^{\circ} \mathrm{C}\right)$, various $\mathrm{pH}$ values $(\mathrm{pH} 5.0-10.0$ at intervals of $1 \mathrm{pH}$ units), and different $\mathrm{NaCl}$ concentrations $(0.5,1,2$, and $3 \% \mathrm{NaCl}(\mathrm{w} / \mathrm{v})$ in YEM broth and agar in 48-96 h bacterial culture. The motility of the bacterial strains was determined by spreading the bacteria inoculated in the centre of $0.3 \%$ YEM agar after 4-5 days of incubation at $28{ }^{\circ} \mathrm{C}$.

Intrinsic antibiotic resistance

Antibiotic resistance was assessed by the ability of the bacteria to grow on YEM medium (Gnat et al. 2014) supplemented with different concentrations of the following antibiotics $(\mathrm{w} / \mathrm{v})$ : streptomycin $(1 \mu \mathrm{g} / \mathrm{ml}$, $5 \mu \mathrm{g} / \mathrm{ml}, \quad 10 \mu \mathrm{g} / \mathrm{ml}, \quad 20 \mu \mathrm{g} /, \quad 25 \mu \mathrm{g} / \mathrm{ml}, \quad 50 \mu \mathrm{g} / \mathrm{ml}$, $100 \mu \mathrm{g} / \mathrm{ml})$, neomycin $(2.5 \mu \mathrm{g} / \mathrm{ml}, 5 \mu \mathrm{g} / \mathrm{ml}, 10 \mu \mathrm{g} /$ $\mathrm{ml}, 20 \mu \mathrm{g} / \mathrm{ml}, 40 \mu \mathrm{g} / \mathrm{ml})$, chloramphenicol (10 $\mu \mathrm{g} / \mathrm{ml}$, $20 \mu \mathrm{g} / \mathrm{ml}, 50 \mu \mathrm{g} / \mathrm{ml}, 100 \mu \mathrm{g} / \mathrm{ml}, 200 \mu \mathrm{g} / \mathrm{ml}$ ), rifampicin $(2.5 \mu \mathrm{g} / \mathrm{ml}, 5 \mu \mathrm{g} / \mathrm{ml}, 10 \mu \mathrm{g} / \mathrm{ml}, 20 \mu \mathrm{g} / \mathrm{ml}, 40 \mu \mathrm{g} /$ $\mathrm{ml})$, tetracycline $(0.5 \mu \mathrm{g} / \mathrm{ml}, 5 \mu \mathrm{g} / \mathrm{ml}, 10 \mu \mathrm{g} / \mathrm{ml})$, ampicillin $(5 \mu \mathrm{g} / \mathrm{ml}, 10 \mu \mathrm{g} / \mathrm{ml}, 20 \mu \mathrm{g} / \mathrm{ml}, 50 \mu \mathrm{g} / \mathrm{ml}$, $100 \mu \mathrm{g} / \mathrm{ml})$, and clindamycin $(500 \mu \mathrm{g} / \mathrm{ml}, 1000 \mu \mathrm{g} /$ $\mathrm{ml}$ ). The plates were incubated at $28^{\circ} \mathrm{C}$ for $72-96 \mathrm{~h}$ and antibiotic resistance was evaluated based on bacterial growth.

Tolerance to dyes

To determine tolerance of bacteria to dyes, they were streaked onto the YEM medium supplemented with the following dyes at different concentrations (\%, w/v): auramine $(0.0065,0.013,0.05,0.2 \%)$; methyl red $(0.05,0.1 \%)$; neutral red $(0.013,0.05,0.1,0.2 \%)$; nigrosine $(0.05,0.1,0.2,0.5 \%)$; acridine orange $(0.0065,0.013,0.2 \%)$; safranin $(0.0065,0.013,0.05$, $0.2 \%)$; and methyl green $(0.0065,0.013 \%)$. The plates were incubated at $28{ }^{\circ} \mathrm{C}$ for $72-96 \mathrm{~h}$ and tolerance to dye was evaluated based on bacterial growth.

Tolerance to heavy metals

Overnight bacterial cultures were streaked on YEM agar medium plates supplemented with different concentrations of heavy metals (w/v): lead in lead acetate $(500 \mu \mathrm{g} / \mathrm{ml}, 750 \mu \mathrm{g} / \mathrm{ml})$, zinc in zinc sulphate $(250 \mu \mathrm{g} / \mathrm{ml}, 500 \mu \mathrm{g} / \mathrm{ml}, 750 \mu \mathrm{g} / \mathrm{ml})$, and cadmium in cadmium chloride $(25 \mu \mathrm{g} / \mathrm{ml}, 50 \mu \mathrm{g} / \mathrm{ml}$ and $100 \mu \mathrm{g} / \mathrm{ml}$ ) (Wani et al. 2008; Elboutahiri et al. 2010). The plates were incubated at $28^{\circ} \mathrm{C}$ for 72-96 $\mathrm{h}$ and metal tolerance was evaluated based on bacterial growth. 
Table 1 O. arvensis microsymbionts and reference strains used in this study

\begin{tabular}{|c|c|c|c|}
\hline Strain & Host plant & Geographic origin & Source \\
\hline $\begin{array}{l}\text { Ononis arvensis microsymbionts: (OA) 2, 4, 24, 38, 43, 47, 52, 61, 67, 100, 108, 109, } \\
118,121,129,132,147,155,156,164,178,179,185,191,192,194,201,245,303\end{array}$ & Ononis arvensis & Poland & ZGM \\
\hline Mesorhizobium amorphae ICMP15022 & Amorpha fruticosa & New Zealand & ICMP \\
\hline Mesorhizobium albiziae CCBAU61158 & Albizia kalkora & China & CCBAU \\
\hline Mesorhizobium caragenae CCBAU11299 & Caragana spp. & China & CCBAU \\
\hline Mesorhizobium chacoense USDA4963 & Prosopis alba & Argentina & USDA \\
\hline Mesorhizobium mediterraneum USDA3392 & Cicer arietineum & Spain & USDA \\
\hline Mesorhizobium ciceri USDA3383 & Cicer arietineum & Spain & USDA \\
\hline Mesorhizobium huakuii USDA4779 & Astragalus sinicus & China & USDA \\
\hline Mesorhizobium loti USDA3471 & Lotus corniculatus & New Zealand & USDA \\
\hline Mesorhizobium plurifarium USDA3707 & Acacia senegal & Senegal & USDA \\
\hline Mesorhizobium septentrionale SDW018 & Astragalus adsurgens & China & CCBAU \\
\hline Mesorhizobium shangrilense CCBAU65327 & Caragana bicolor & China & CCBAU \\
\hline Mesorhizobium temperatum LMG23931 & Astragalus adsurgens & China & LMG \\
\hline Mesorhizobium tianshanense USDA3592 & Glycyrrhiza pallidiflora & China & USDA \\
\hline Bradyrhizobium elkanii USDA76 & Glycine $\max$ & USA & USDA \\
\hline Bradyrhizobium sp. (Lupinus) USDA 3045 & Lupinus sp. & USA & USDA \\
\hline Bradyrhizobium liaoningense USDA 3622 & Glycine $\max$ & USA & USDA \\
\hline Bradyrhizobium japonicum USDA6 & Glycine $\max$ & USA & USDA \\
\hline \multicolumn{4}{|l|}{ Neorhizobium galegae } \\
\hline HAMBI1141 & Galega officinalis & New Zealand & HAMBI \\
\hline HAMBI1155 & Galega orientalis & New Zealand & HAMBI \\
\hline HAMBI1185 & Galega officinalis & New Zealand & HAMBI \\
\hline \multicolumn{4}{|l|}{ Rhizobium leguminosarum } \\
\hline bv. trifolii 21 & Trifolium sp. & Poland & ZGM \\
\hline bv. trifolii ANU843 & Trifolium sp. & Poland & ZGM \\
\hline bv. viciae 1 & Vicia sp. & Poland & ZGM \\
\hline bv. viciae 2 & Vicia sp. & Poland & ZGM \\
\hline bv. viciae 33 & Vicia sp. & Poland & ZGM \\
\hline bv. viciae 36 & Vicia sp. & Poland & ZGM \\
\hline bv. viciae 3841 & Vicia sp. & Poland & ZGM \\
\hline Rhizobium tropici OUT21 & Phaseolus sp. & USA & USDA \\
\hline \multicolumn{4}{|l|}{ Ensifer fredii } \\
\hline USDA1-6 & Glycine sp. & China & USDA \\
\hline USDA16-1 & Glycine sp. & China & USDA \\
\hline USDA440 & Glycine sp. & China & USDA \\
\hline \multicolumn{4}{|l|}{ Ensifer meliloti } \\
\hline SU47 & Medicago sativa & Australia & NZP \\
\hline 11 & Medicago sativa & Poland & ZGM \\
\hline 13 & Medicago sativa & Poland & ZGM \\
\hline L5-30 & Medicago sativa & Poland & ZGM \\
\hline L54 & Medicago sativa & Poland & ZGM \\
\hline MVII & Medicago sativa & Poland & ZGM \\
\hline
\end{tabular}

ZGM Department of Genetics and Microbiology, University of Maria Curie-Skłodowska, Lublin, Poland; USDA United States Department of Agriculture, Beltsville, MD, USA; ATCC American Type Culture Collection, Rockville, MD; ICMP International Collection of Microorganisms from Plants, Landcare Research, Auckland, New Zealand; LMG Belgian Coordinated Collections of Microorganisms/LMG Bacteria Collection, Ghent University, Belgium; NZP Division of Scientific and Industrial Research, Palmerston North, New Zealand 
Siderophore production

The siderophore production was detected by the chrome azurol sulfonate (CAS) plate assay described by Louden et al. (2011). We used Ensifer meliloti SU47 as a positive control because this strain has been described as a producer of siderophores. The negative control was CAS medium without inoculation.

\section{Other tests}

The activity of urease, catalase, galactosidase, gluconidase, nitrate reductase, oxidase, peroxidase, and phosphatase as well as litmus milk reaction were tested (Gnat et al. 2014). Melanin production was determined with the method developed by Cubo et al. (1988). Congo Red absorption was studied in YEM medium with $0.0025 \%$ (wt/vol) dye (Wdowiak-Wrobel and Malek 2000) and the precipitation of calcium glycerophosphate was checked according to the Hoffer method (1941). Production of indole in tryptophan broth was studied (Gnat et al. 2014). IAA production was examined with the method described by Wdowiak-Wrobel and Malek (2016). The phosphate solubilizing ability of the studied bacteria was tested on Pikovskaya's agar (Gupta et al. 2012) containing tricalcium phosphate (TCP) as an insoluble phosphate source. The formed halo zone surrounding the colony revealed phosphate solubilization (Arun and Sridhar 2005).

Numerical analysis

The phenotypic features of the bacteria were coded in the binary system. The similarity rate of the strains was determined by a simple matching (SM) coefficient and their clustering with the UPGMA method using the software NTSYS package.

\section{DNA isolation}

Total DNA was isolated using the guanidium thiocyanate method described by Pitcher et al. (1989). The DNA concentration and its purity were determined with a spectrophotometer (Bio-Rad, SmartSpec ${ }^{\mathrm{TM}}$ 3000).

rep-PCR analysis

Bacterial DNA fingerprints were obtained with the BOX-PCR method using the primer BOX2AR 5'-
CTCCGGCAAGGCGACGCTGAC-3' (Louws et al. 1994). PCR was performed using a ReadyMix ${ }^{\mathrm{TM}} \mathrm{Taq}$ kit, following manufacturer's specifications (SigmaAldrich), i.e., $3 \mathrm{~min}$ at $95{ }^{\circ} \mathrm{C}, 35$ cycles of $1 \mathrm{~min}$ at $94{ }^{\circ} \mathrm{C}, 1 \mathrm{~min}$ at $53{ }^{\circ} \mathrm{C}, 8 \mathrm{~min}$ at $65^{\circ} \mathrm{C}$, and finally 16 min at $65{ }^{\circ} \mathrm{C}$. The PCR products were identified by electrophoresis on $1.5 \%$ agarose gels in $1 \times \mathrm{TBE}$ buffer. An analysis of the amplified fragments was carried out using the BIO1D v. 11.10 program (VilberLourmat, France). The strains were grouped by the Nei and Li coefficient (Nei and Li 1979) and the dendrogram was constructed using the UPGMA method.

16S rRNA, nodC, and acdS gene amplification

The 16S rRNA gene was amplified by PCR using two primers $\mathrm{fD} 1$ and $\mathrm{rD} 1$ according to the procedure described by Weisburg et al. (1991).

The nodC gene of the $O$. arvensis isolates was amplified by PCR with primers nodCFu and nodCI using cycle parameters reported by Laguerre et al. (2001).

The $a c d S$ gene was amplified by PCR using primers acdSF (5'-CAAGCTGCGCAAGCTCGAATA- $\left.{ }^{\prime}\right)$ and acdSR (5'-CATCCCTTGCATCGATTTGC-3'), which were designated by analysis of corresponding sequences of bacterial strains available in the GenBank database. The amplification reaction was performed according to the manufacturer's description using a $25 \mu \mathrm{l}$ reaction mixture (Sigma-Aldrich) under the following conditions: initial denaturation for $5 \mathrm{~min}$ at $95{ }^{\circ} \mathrm{C}$ followed by 30 cycles of $30 \mathrm{~s}$ at $95{ }^{\circ} \mathrm{C}, 30 \mathrm{~s}$ at $50{ }^{\circ} \mathrm{C}$, and $1 \mathrm{~min}$ at $72{ }^{\circ} \mathrm{C}$ and then a final 5 -min elongation step at $72{ }^{\circ} \mathrm{C}$.

The amplicons of all the genes were electrophoresed on $1 \%(\mathrm{w} / \mathrm{v})$ agarose gel and then purified using a Cleanup kit (A\&A Biotechnology). Sequencing reactions were performed using the BigDye Terminator Cycle Sequencing Kit (Applied Biosystems, USA). The products obtained were cleaned with an Ex-Terminator kit (A\&A Biotechnology) and analysed in an automatic 3500 Genetic Analyzer sequencer (Applied Biosystems). The sequences of $16 \mathrm{~S}$ rRNA, nodC, and acdS genes were compared with the sequences available in the GenBank and were aligned using ClustalX2 multiple sequence alignment (Larkin et al. 2007). The sequence similarity rate was determined according to the Kimura two-parameter model (Kimura 1980). Phylogenetic trees of the strains studied were constructed using the neighbour-joining method. Bootstrap analysis was based on 1000 resamplings. The MEGA 
4.0 version (Tamura et al. 2007) was used for all gene sequence analyses. The positive control was genomic DNA extracted from Mesorhizobium loti USDA3471 and Rhizobium leguminosarum bv. trifolii ANU843 strains. The negative control was the reaction mixture minus the DNA template (PCR master mix and nuclease-free water instead of DNA).

Nucleotide sequence accession numbers

The GenBank accession numbers for the 16S rRNA gene sequences of $O$. arvensis microsymbionts OA4, OA118, OA121, OA129, OA132, OA245, and OA191 are KU248351-KU248357. The accession numbers of the nodC gene sequences for OA4, OA129, OA132, OA245, OA118, OA191, and OA121 are KU248358KU28364. The GenBank accession numbers for the acdS gene sequences reported in this study (OA121, OA129, OA4, OA118, OA191, OA132, and OA245) are KU248365-KU248371.

Nodulation tests

Seeds of Trifolium repens, Medicago sativa, and Lotus corniculatus were surface sterilized for $3 \mathrm{~min}$ in $3 \%$ sodium hypochlorite and next washed several times in sterile distilled water. $O$. arvensis and $O$. spinosa seeds were first immersed in concentrated sulfuric acid for $20 \mathrm{~min}$ and afterwards washed in sterile distilled water. All seeds were germinated on sterilized water-agar $(0.8 \%)$ and the seedlings obtained were transferred (one per tube) on sterile nitrogen-free medium slants (Gnat et al. 2015). Three days later, the seedlings rootlets were inoculated with $\sim 10^{8}$ bacterial cells. The plants were grown for 6-7 weeks in a greenhouse under natural light supplemented with artificial light $\left(200 \mu \mathrm{E} \mathrm{m}^{-2} \mathrm{~s}^{-1}, 14 \mathrm{~h}\right.$ day/ $10 \mathrm{~h}$ night, at $24 / 19^{\circ} \mathrm{C}$ ). Ten tubes were used for each isolate. Non-inoculated plants were used as negative controls. Symbiotic effectivity of rhizobia was estimated based on their nodule formation and the dry weight of shoots of inoculated plants compared to the control.

\section{Results}

Phenotypic analysis

The bacteria studied were isolated from $O$. arvensis root nodules. In total, 29 isolates were confirmed to be rhizobia by the authentication test with their native host plant (data not shown). All these bacteria formed effective symbiosis with their native host plant (data not presented). They were Gram-negative, rod-shaped bacteria that formed, circular, convex and colourless colonies, $2-3 \mathrm{~mm}$ in diameter, on YEM agar after 2-4 days of growth at $28{ }^{\circ} \mathrm{C}$.

The bacteria grew at temperatures from 4 to $37{ }^{\circ} \mathrm{C}$ and the optimum temperature for their growth was $28^{\circ} \mathrm{C}$. The $\mathrm{pH}$ range of the $O$. arvensis symbionts was from 5 to 10, except for 3 isolates (OA121, OA156 and $\mathrm{OA} 245)$ that did not grow at $\mathrm{pH} 10$. None of the $O$. arvensis isolates demonstrated an ability to grow at $\mathrm{pH}$ 4. The strains exhibited good tolerance to salinity. All of them grew in the presence of $0.5 \% \mathrm{NaCl}$ in the medium, and thirteen of them grew at $3 \% \mathrm{NaCl}$.

It was observed that the isolates studied were able to metabolize a wide range of substrates as a sole carbon source. All strains used 19 from the 30 compounds studied. Eleven carbon sources were used by $87-96 \%$ of the nodule isolates. Three of the 16 compounds tested as a sole $\mathrm{N}$ source for $O$. arvensis microsymbionts, i.e., methionine, isoleucine, and proline, were utilized by all strains. None of the tested strains was able to utilise histidine, valine, and glycine (Table 2).

The analysis of the intrinsic bacterial resistance to antibiotics showed that the bacteria were generally resistant to the antibiotics used, except tetracycline, which inhibited rhizobial growth already at $5 \mu \mathrm{g} / \mathrm{ml}$ in the medium (Table 2).

The results obtained showed that all isolates were urease, nitrate reductase, and beta-D-glucosidase (esculinase) positive and absorbed Congo Red from the agar medium. Most of the tested isolates were phosphatase $(72 \%)$, oxidase $(65 \%)$, and catalase $(58 \%)$ positive, produced IAA $(72 \%)$, and were capable of phosphate solubilization $(96 \%)$, calcium glycerophosphate precipitation $(68 \%)$, and melanin production $(44 \%)$.

Numerical analysis

The numerical analysis of 126 physiological and biochemical properties of $O$. arvensis microsymbionts showed their wide phenotypic diversity (Fig. 1). The dendrogram constructed based on this analysis placed the bacteria studied and reference strains in two main clusters at a $51 \%$ similarity level (Fig. 1). One cluster contained 15 rhizobial strains specific for $O$. arvensis 
Table 2 Characteristics of $O$. arvensis strains and related Mesorhizobium and Rhizobium species

\begin{tabular}{|c|c|c|c|c|c|c|c|}
\hline Characteristics & $\begin{array}{l}\text { Ononis arvensis } \\
\text { microsymbionts } \\
(\mathrm{n}=29)\end{array}$ & $\begin{array}{l}\text { M. loti } \\
\text { NZP } \\
2213^{\mathrm{T}}\end{array}$ & $\begin{array}{l}\text { M. ciceri } \\
\text { USDA } \\
3383^{\mathrm{T}}\end{array}$ & $\begin{array}{l}\text { M. tarimense } \\
\text { CCBAU } \\
83306^{\mathrm{T}}\end{array}$ & $\begin{array}{l}R . \\
\text { leguminosarum } \\
\text { USDA } 2370^{\mathrm{T}}\end{array}$ & $\begin{array}{l}\text { R. pisi } \\
\text { DSM } \\
30132^{\mathrm{T}}\end{array}$ & $\begin{array}{l}\text { R. fabae } \\
\text { LMG } \\
23997^{\mathrm{T}}\end{array}$ \\
\hline \multicolumn{8}{|c|}{ Utilization of compounds as sole carbon sources } \\
\hline Raffinose & +26 & + & - & - & + & + & + \\
\hline Sodium citrate & +5 & - & - & - & - & - & + \\
\hline Dulcitol & +27 & + & + & - & + & + & + \\
\hline Inulin & + & + & - & - & + & - & - \\
\hline L-Lysine & +21 & + & - & - & + & - & nd \\
\hline D-Mannose & + & + & + & - & + & + & + \\
\hline Salicin & +28 & - & - & - & + & + & + \\
\hline Starch & +11 & + & - & - & + & + & - \\
\hline L-Tyrosine & +14 & + & - & nd & - & nd & - \\
\hline L-Arginine & +8 & + & - & + & - & - & + \\
\hline \multicolumn{8}{|c|}{ Utilization of compounds as nitrogen sole sources } \\
\hline L-Alanine & +28 & - & + & - & + & - & + \\
\hline L-Glycine & - & - & - & - & - & nd & + \\
\hline L-Valine & - & - & - & - & - & - & + \\
\hline L-Phenylalanine & +10 & + & + & - & nd & nd & + \\
\hline \multicolumn{8}{|l|}{ Tolerance to $\mathrm{pH}$} \\
\hline 4 & - & \pm & - & - & - & - & - \\
\hline 5 & + & + & + & - & - & + & + \\
\hline \multicolumn{8}{|c|}{ Tolerance to $\mathrm{NaCl}(\%)$} \\
\hline 1 & +26 & + & + & - & - & + & + \\
\hline 2 & +14 & - & + & - & - & - & + \\
\hline \multicolumn{8}{|c|}{ Antibiotic resistance $\left(\mu \mathrm{g} \mathrm{ml}^{-1}\right)$} \\
\hline $\begin{array}{l}\text { Chloramphenicol } \\
20\end{array}$ & +22 & - & + & - & + & nd & + \\
\hline Ampillicin 50 & +18 & + & - & - & - & nd & - \\
\hline Neomycin 20 & +20 & - & - & + & + & + & + \\
\hline Tetracycline 30 & - & - & - & + & - & - & - \\
\hline Streptomycin 50 & +12 & + & + & - & + & nd & + \\
\hline
\end{tabular}

Strains: Mesorhizobium loti NZP 2213 ${ }^{\mathrm{T}}$ (Jarvis et al. 1982, 1997), Mesorhizobium ciceri USDA 3383 ${ }^{\mathrm{T}}$ (Nour et al. 1994), Mesorhizobium tarimense CCBAU 83306 ${ }^{\mathrm{T}}$ (Han et al. 2008), Rhizobium leguminosarum USDA 2370 ${ }^{\mathrm{T}}$ (Ramírez-Bahena et al. 2008), Rhizobium pisi DSM $30132^{\mathrm{T}}$ (Ramírez-Bahena et al. 2008), Rhizobium fabae LMG $23997^{\mathrm{T}}$ (Tian et al. 2008)

+ positive; \pm weakly positive; - negative; $n d$ no data available

and 13 reference strains of the genera Rhizobium and Ensifer. The second cluster included $14 O$. arvensis symbionts and 11 reference strains of the genus Mesorhizobium (Fig. 1).

Tolerance to heavy metal

The 29 O. arvensis microsymbionts were tested for their ability to tolerate various concentrations of heavy metals (cadmium, lead, and zinc) using the streak plate technique. Generally, the strains showed a varied level of tolerance to the heavy metals examined. The $O$. arvensis nodule isolates showed the greatest intrinsic sensitivity to cadmium. Most of them grew in the presence of $50 \mu \mathrm{g}$ of cadmium per $\mathrm{ml}$ of the medium and $20 \%$ tolerated even $100 \mu \mathrm{g}$ of cadmium per ml of medium. Seven of them (OA47, OA61, OA67, OA100, OA108, OA155, OA303) were highly 


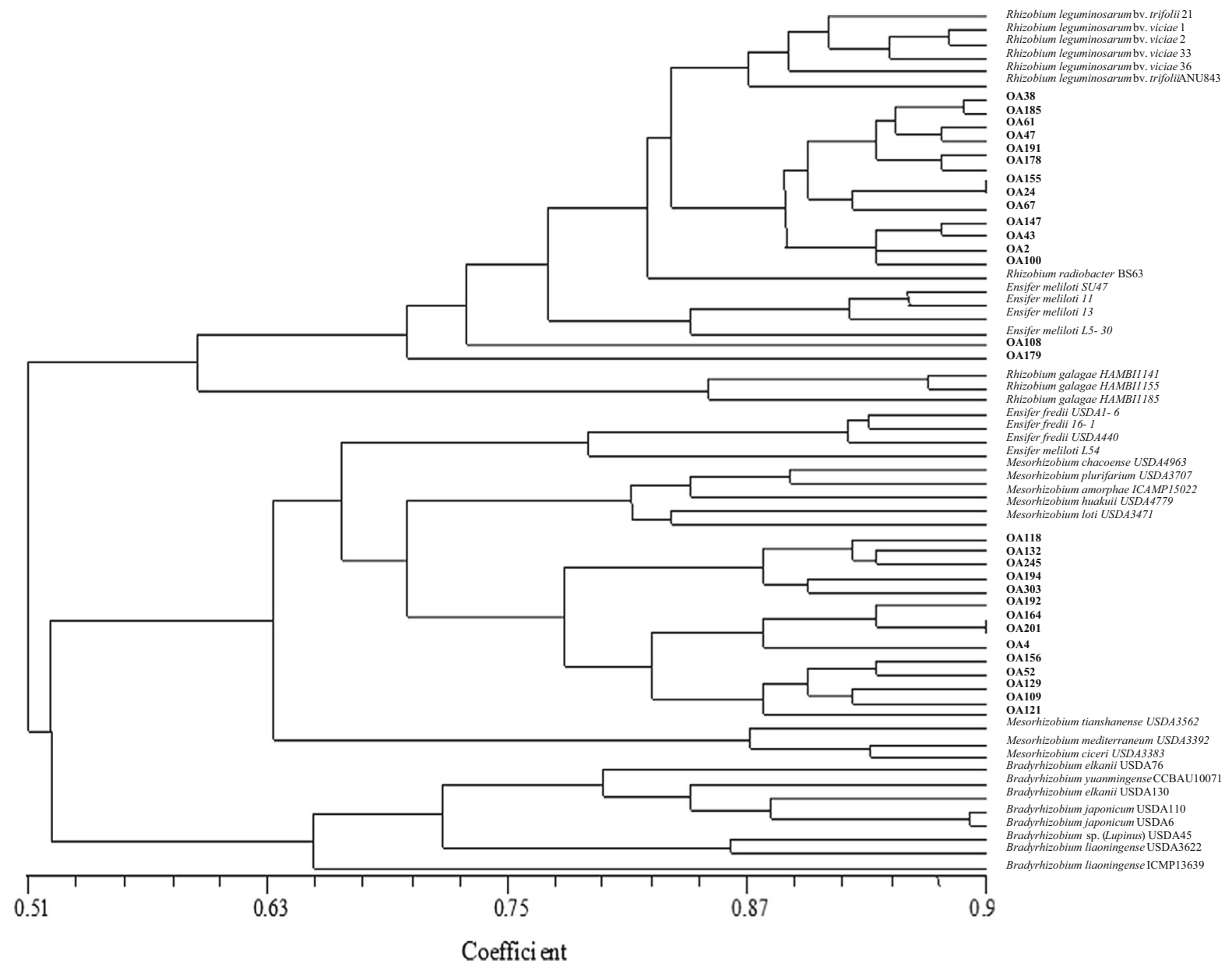

Fig. 1 Dendrogram highlighting the phenotypic similarities among rhizobia specific for $O$. arvensis compared with reference species using Jaccard's similarity coefficients (UPGMA) method

resistant to the three heavy metals studied (cadmium, lead, and zinc).

\section{Siderophore production}

Only six (OA2, OA108, OA109, OA118, OA147, OA43) of the 29 O. arvensis microsymbionts produced siderophores, which was demonstrated by formation of orange halos surrounding the spots with bacterial growth on the CAS agar medium.

BOX-PCR genomic fingerprints

Purified total DNAs from the 29 O. arvensis microsymbionts were used as templates for PCR with the BOX primer to generate bacterial genomic fingerprints
(Fig. 2). In the phylogram based on DNA profiles, the $O$. arvensis microsymbionts were grouped into two clusters at $49 \%$ DNA pattern similarity. The bacteria specific for $O$. arvensis showed 27 unique fingerprinting types specific to each strain. Only three strains, i.e., OA24, OA155, and OA191, showed identical DNA fingerprinting patterns.

In total, 593 DNA fragments ranging in size from 593 bp to 9392 bp were obtained using the amplification reaction with the $\mathrm{BOX}$ primer and used for construction of a dendrogram by the BIO1D v. 11.10 (Vilber-Lourmat) program (Fig. 2). This analysis showed a high level of genomic diversity among the $O$. arvensis rhizobia studied. The DNA pattern similarity of these bacteria determined by the BOX-PCR method was in the range from 49 to $100 \%$ (Fig. 2). 


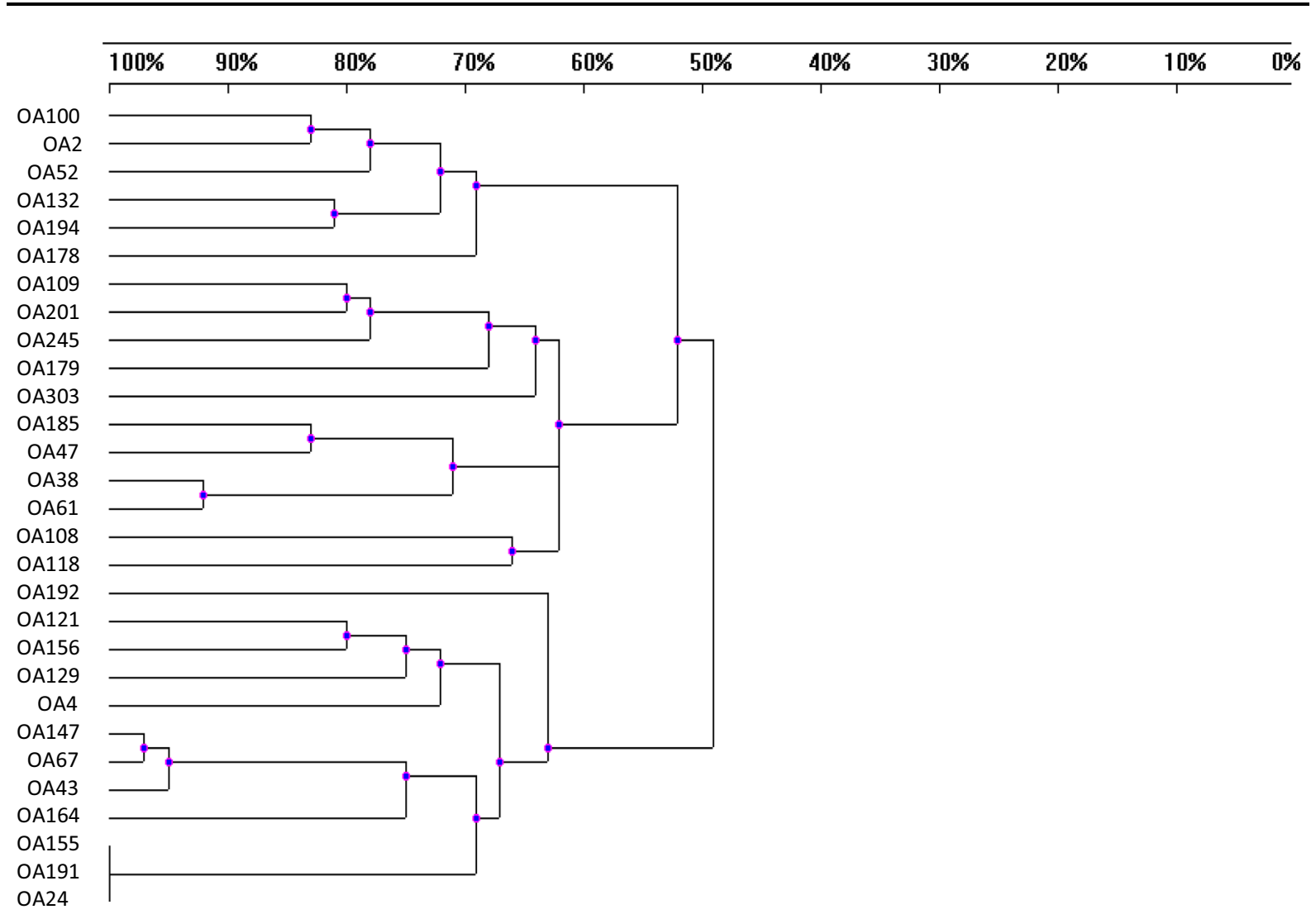

Fig. 2 Similarity UPGMA tree of BOX-PCR patterns of 29 O. arvensis microsymbionts

16S rRNA gene sequence analysis

In the phylogenetic studies, seven strains representing two groups of $O$. arvensis symbionts identified by the BOX-PCR analysis were used. The comparative $16 \mathrm{~S}$ rRNA gene sequence analysis of these bacteria (with 92-99\% 16S rRNA gene sequence similarity to each other) and 46 reference rhizobia representing different genera and species of nodule bacteria showed that the isolates studied belong to two genera, i.e., Mesorhizobium and Rhizobium (Fig. 3). In the 16S rRNA gene phylogram, three isolates, OA118, OA132, and OA191, were placed close to the $R$. leguminosarum strains (98-99\% sequence similarity) (Fig. 3). The other four isolates, OA4, OA121, OA129, and OA245, were grouped with the genus Mesorhizobium strains in one monophyletic cluster with a bootstrap support of $100 \%$ (Fig. 3). Three of them (OA4, OA121, and OA129) were close phylogenetic neighbours of $M$. loti strain NZP 2213 (97-100\% sequence similarity). Strain OA245 formed a clearly separate lineage together with Mesorhizobium ciceri strain UPM-Ca7 (98\% sequence similarity).

nodC gene analysis

The phylogenetic tree built with the partial sequences of nod $C$ genes split $O$. arvensis microsymbionts that showed from 69 to $99 \%$ similarity to each other into three clades (Fig. 4). The first clade was composed of four $O$. arvensis rhizobia (OA4, OA121, OA129, $\mathrm{OA} 245)$ as well as M. loti NZP2213 and M. tarimense CCBAU83306 strains as the close neighbours (98-99\% sequence similarity) (Fig. 4). The second one, supported by $100 \%$ bootstrap, comprised the OA191 strain, Rhizobium pisi DSM30132 (98\% nodC gene similarity), and $R$. leguminosarum bv. viciae USDA 2370 ( $97 \%$ sequence similarity). The two other strains, i.e., OA118 and OA132, were close phylogenetic neighbours of R. leguminosarum bv. trifolii ATCC14480 and exhibited 94 and $96 \%$ nodC gene sequence similarities with this strain, respectively. 


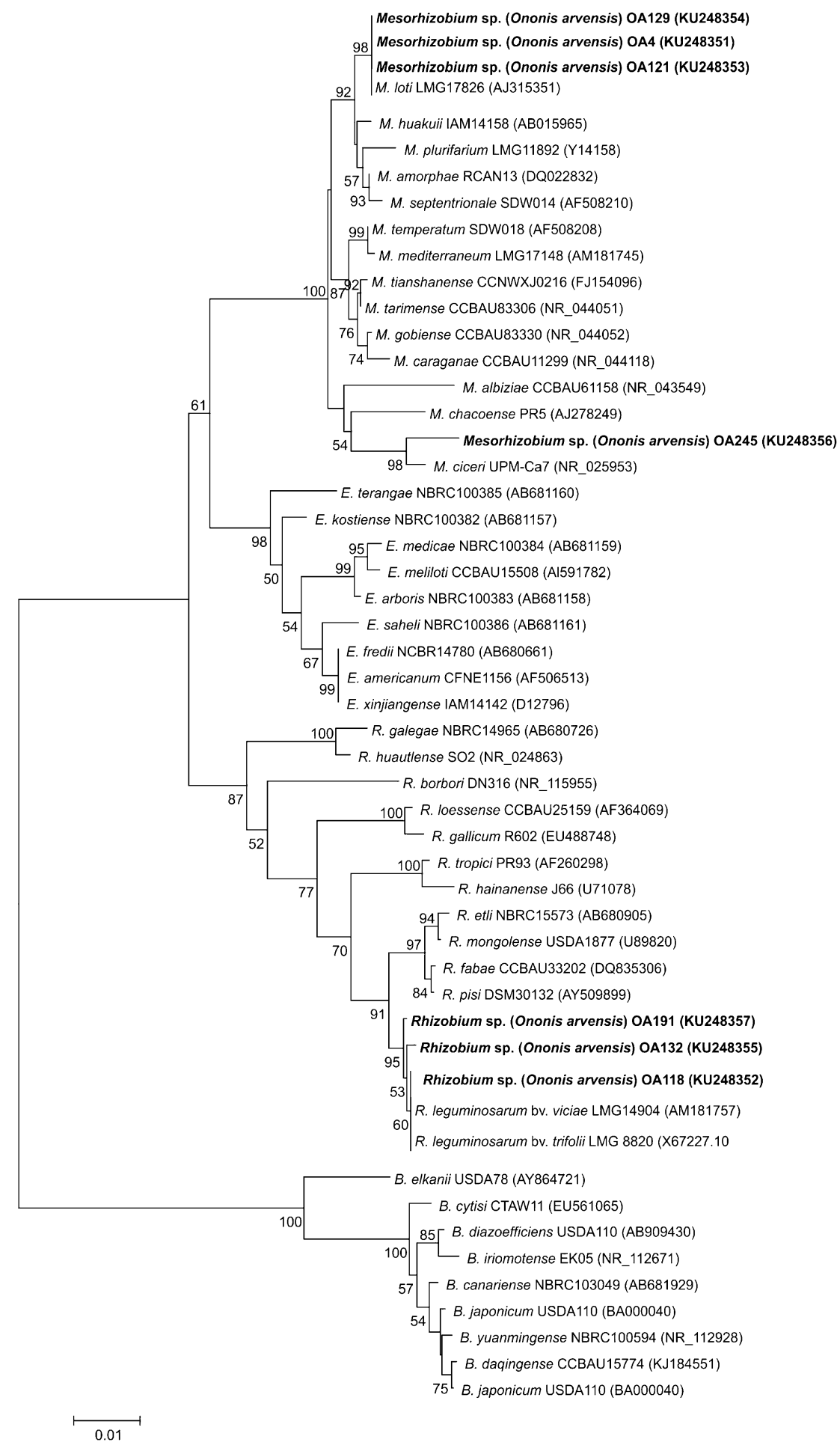

Fig. 3 Phylogenetic tree based on partial sequences of the 16S rRNA gene of isolates specific for O. arvensis and other rhizobia. The tree was constructed using the neighbour-joining method. Bootstrap values are indicated at the nodes (only values greater than $50 \%$ are shown). The scale bar at the bottom left represents 0.01 nucleotide substitution per site 
Fig. 4 Phylogenetic tree derived from nodC gene sequences data. The tree was constructed using the neighbour-joining method. Bootstrap values are indicated at the nodes (only values greater than $50 \%$ are shown). The scale bar indicates 0.05 nucleotide substitution per site

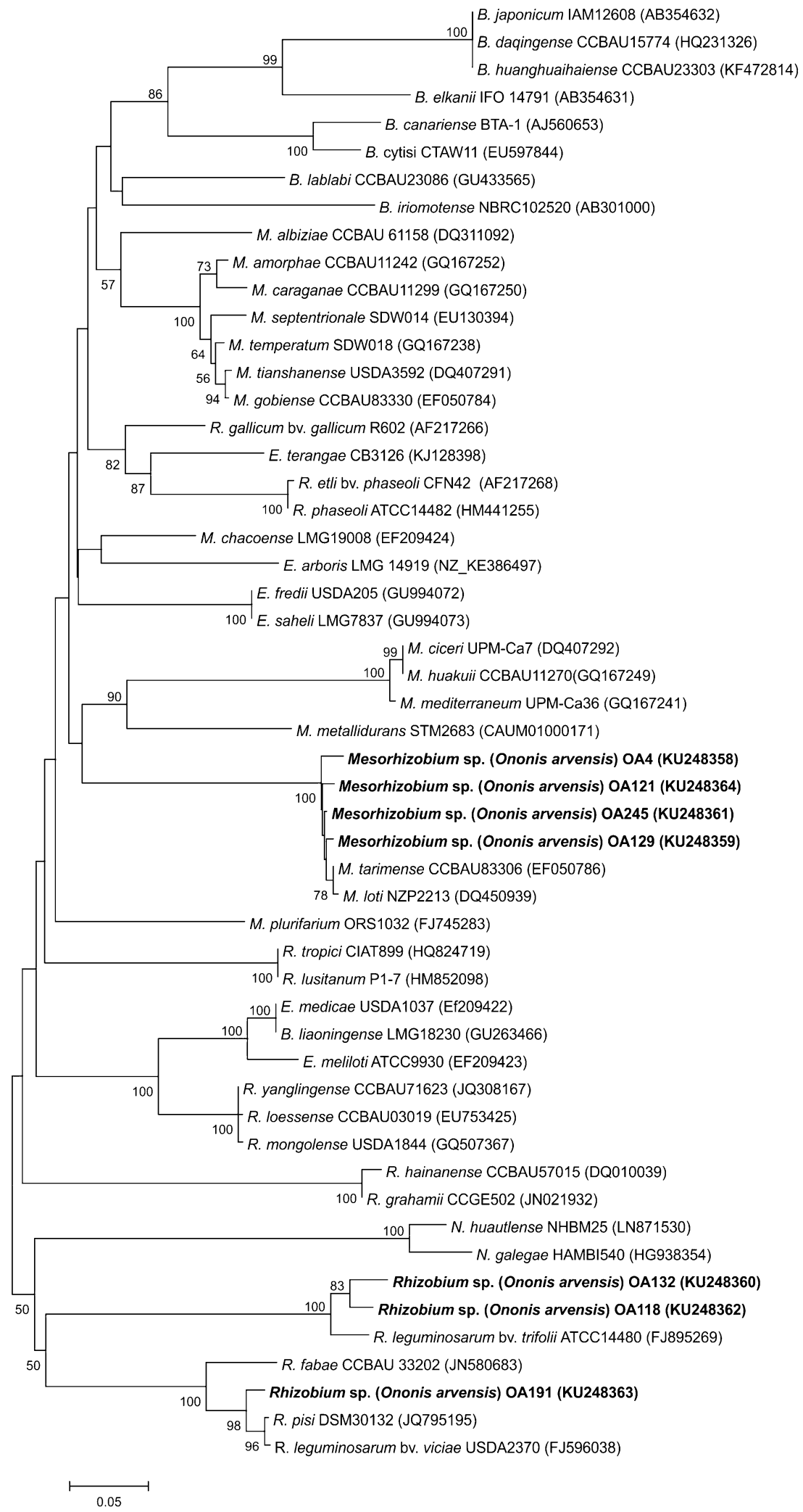


acd $S$ gene analysis

The nucleotide sequences of the acdS genes of seven $O$. arvensis nodule isolates, OA4, OA118, OA121, OA129, OA132, OA191, and OA245, were compared to those from the GenBank sequence database (Fig. 5). All the strains studied, with 91-98\% acdS sequence similarities to each other, formed a common cluster with M. loti NZP2213 and M. tarimense CCBAU83306 as close phylogenetic neighbour (91-99\% sequence similarity) and a larger cluster with the other Mesorhizobium species included in the analysis (80-99\% acdS gene sequence similarity) (Fig. 5). The acdS sequence similarities of $O$. arvensis rhizobia and Bradyrhizobium sp., Ensifer sp., Rhizobium sp., and Azorhizobium caulinodans were substantially lower, i.e., 65-76\%, $61-66 \%, 77-81 \%$, and $72-75 \%$, respectively.

Nodulation tests

29 isolates from $O$. arvensis nodules, identified on the basis of phenotypic properties and 16S rRNA gene sequence analysis as members of the genus Mesorhizobium and Rhizobium, were studied for host plant

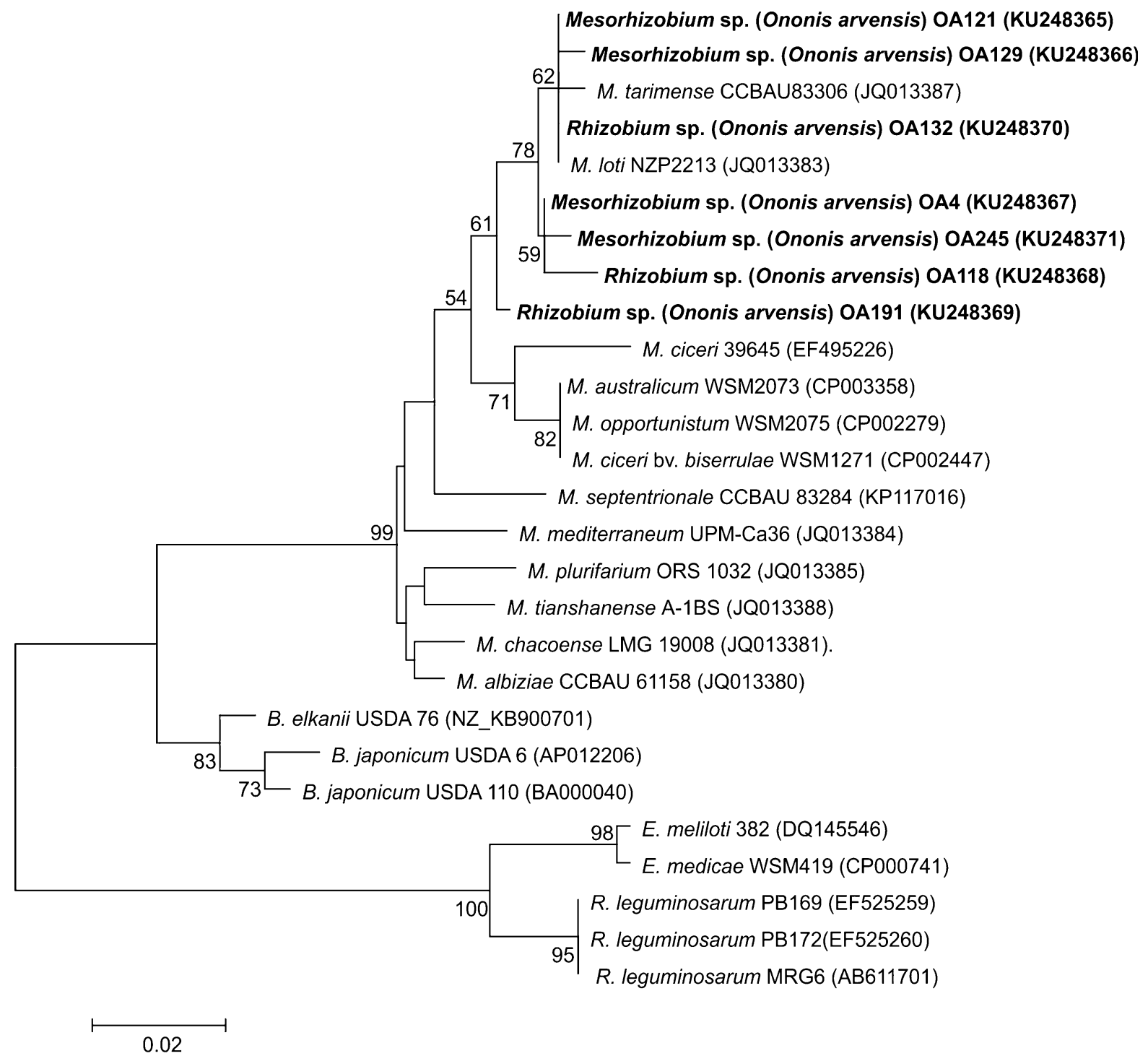

Fig. 5 Neighbour-joining acdS phylogenetic tree of $O$. arvensis symbionts and rhizobial reference strains. Bootstrap values are indicated at the nodes (only values greater than $50 \%$ are shown). The scale bar indicates the number of substitutions per site 
specificity and nitrogen-fixing ability. All the studied isolates were able to induce nodules and fix nitrogen in the symbiotic interaction with their native host plant, as shown by the formation of pink nodules (2-4 per plant) as well as the dark green colour and the dry weight of aerial parts of the inoculated plants, compared with the noninoculated ones. The shoot dry weight of $O$. arvensis inoculated with the studied isolates was 1.85-2.5-fold higher than that of non-inoculated plants.

The nodule inducing and nitrogen fixing abilities of restharrow symbionts were also checked on selected fabacean species that represented hosts of the close relatives of the studied isolates, i.e., $O$. spinosa, $T$. repens, $M$. sativa, and $L$. corniculatus. The nodulation test indicated that $55 \%$ of these bacteria nodulated $O$. spinosa and formed pink nodules (1-2 per plant) on this plant; however, rhizobia in this symbiotic association were less effective in $\mathrm{N}_{2}$ fixation than in the interaction with $O$. arvensis. Six weeks after inoculation of $O$. spinosa with the tested bacteria, the shoot dry weight of these plants was 1.4-2.2-fold higher compared to the noninoculated plants. None of our isolates nodulated $T$. repens, $M$. sativa, and $L$. corniculatus.

In contrast to the narrow host range of $O$. arvensis symbionts, their native host (restharrow) exhibited (in laboratory plant tests) a wide range of promiscuity and entered mutualistic interactions with M. loti, Mesorhizobium huakuii, M. ciceri, Mesorhizobium septentrionale, Mesorhizobium albiziae, Mesorhizobium caraganae, Rhizobium etli, Rhizobium tropici, and $R$. leguminosarum bv. viciae, but not with Bradyrhizobium, Neorhizobium and Ensifer strains.

\section{Discussion}

Currently, polyphasic taxonomy based on different types of data (phenotypic, genomic, phylogenetic) is used in defining the taxonomic position of microorganisms (Vandamme et al. 1996; Young and Haukka 1996; Niemann et al. 1997). In this study, using the polyphasic approach, we characterized 29 strains isolated from root nodules of $O$. arvensis growing in the south-eastern part of Poland.

Up to now, the phylogenetic position and symbiotic properties of field restharrow microsymbionts have not been characterized and described. The isolates studied have an ability to utilize a wide range of various compounds as sole carbon and nitrogen sources. It was also noted that all of them were fast growers, produced acid on the yeast extract mannitol medium, and formed colonies of 2-3 $\mathrm{mm}$ in diameter after 2-3 days of growth at $28^{\circ} \mathrm{C}$ on this agar. The capability of acidification of the medium with mannitol is characteristic for fast-growing bacteria, which are also able to utilize different disaccharides. The fast growing rhizobia mainly include nodule bacteria establishing symbiosis with e.g., alfalfa and clover, i.e., plants which belong to the same tribe as the host of the studied isolates. In contrast to fast growing rhizobia, slow growing nodule bacteria cause alkalization of YEM medium and are represented by soybean and cowpea rhizobia (Boakye et al. 2016).

The numerical analysis of the phenotypic properties showed that the $O$. arvensis symbionts are representative of bacteria of the genera Rhizobium, Ensifer, and Mesorhizobium.

The analysis of the plant growth promoting features of the $O$. arvensis microsymbionts showed that $100 \%$ of them were able to produce urease and had phosphate-solubilizing activity. More than $93 \%$ of these bacteria (27 strains) produced IAA acid. Research conducted by Antoun et al. (1998) showed that many Bradyrhizobium sp. and Rhizobium sp. strains produced siderophores and IAA and solubilized phosphate. IAA production by Rhizobium sp. strains has also been described by some other authors (Badenoch-Jones et al. 1983; Spaepen and Vanderleyden 2011) and it has been shown that auxin balance in the plant is important for proper nodule organogenesis and for many processes such as division and differentiation of plant cells and formation of vascular bundles (Mathesius et al. 1998).

It is known that the ability of rhizospheric bacteria to synthesize siderophores, antibiotics, $\mathrm{HCN}$, and enzymes such as, e.g., ACC deaminase, phosphatase, chitinase, and urease, is important in the battle against plant root pathogens (Nagarajkumar et al. 2004). Such bacteria are good candidates for plant growth promotion and have a beneficial effect on plant development. It was noted that ACC deaminase synthesized by rhizospheric and endosymbiotic bacteria frequently serves to overcome ethylene stress in plants The presence of active ACC deaminase has been described previously in rhizobial species such as $M$. loti, $R$. leguminosarum bv. viciae, and Rhizobium hedysari 
(Ma et al. 2003; Hao et al. 2011; Gopalakrishnan et al. 2015).

Production of siderophores was detected in the $O$. arvensis microsymbionts (34.4\%). The ability to produce siderophores has also been described for Rhizobium leguminosarium bv. viciae, Rhizobium leguminosarium bv. trifolii, E. meliloti, Bradyrhizobium japonicum, and M. ciceri (Guerinot et al. 1990; Reigh and O'Connell 1993; Raychaudhuri et al. 2005). The symbiotic rhizobium-legume plant interaction is iron-dependent, since the presence of this element is necessary for the functioning of some enzymes such as leghemoglobin, nitrogenase, and ferredoxin. Studies have shown that siderophore-producing bacteria positively influence plant growth and the efficiency of host plant nodulation (de Souza et al. 2015).

Methods based on DNA polymorphism analysis are used for identification and differentiation of bacteria. They include, inter alia, restriction fragment length polymorphism (RFLP) analysis, rep-PCR DNA fingerprinting techniques (repetitive sequence-based PCR), and AFLP (amplified fragment length polymorphisms) (Thies et al. 2001; Albuquerquea et al. 2009).

rep-PCR techniques (ERIC-PCR, BOX-PCR, and REP-PCR) facilitate differentiation of strains even within a single species. The BOX-PCR method is a useful tool in distinguishing and identifying bacteria (Gillings and Holley 1997; Rademaker et al. 2000; Thies et al. 2001; Brusetti et al. 2008). Our results based on the BOX-PCR technique demonstrated wide genomic variation of the $O$. arvensis microsymbionts. It should also be noted that the use of this method may be useful in rapid identification of field restharrow strains.

Analysis of $16 \mathrm{~S}$ rRNA gene sequences has been widely used for determining the phylogenetic relationship and taxonomic position (mainly genus) of bacterial strains. However, in recent years, it has been found that the resolving power of this technique is limited and it does not allow differentiation of closely related species or even some closely related genera (Rajendhran and Gunasekaran 2011). It has been established that two organisms that have less than $97 \%$ sequence similarity of 16S rRNA gene belong to two different species, whereas those with at least 95\% 16S rRNA gene sequence similarity belong to the same genus (Rosselló-Mora and Amann 2001; Rajendhran and Gunasekaran 2011).

The phylogenetic analysis based on 16S rRNA gene sequence analysis of seven $O$. arvensis strains (OA4,
OA118, OA121, OA129, OA132, OA191 and OA245), representing two genomic groups obtained with the BOX-PCR method showed that rhizobia specific for the restharrow are a phylogenetically diverse group of microorganisms and represent two genera Rhizobium and Mesorhizobium. Four of them, OA4, OA121, OA129, and OA2445, were classified to the genus Mesorhizobium. The remaining three microsymbionts, OA118, OA132, and OA191, formed a common monophyletic cluster with $R$. leguminosarum strains and were affiliated to the genus Rhizobium.

Similarly, isolates from root nodules of Ononis tridentata L., a plant belonging to the same genus as $O$. arvensis, showed (based on 16S rRNA gene sequence analysis) a phylogenetic relationship with bacteria of the genera Rhizobium and Mesorhizobium, but some of them also with Phylobacterium and Bosea (Rincón et al. 2008).

The rhizobial nod and nif genes are symbiotic, adaptive genes. Some studies suggest that they very often have evolutionary history independent of the housekeeping genes explained by a lateral transfer of nod loci even across divergent chromosomal lineages, as in the case of rhizobia representing the genus Rhizobium and Ensifer (Wang et al. 2007). Horizontal transfer of nodulation genes may adapt rhizobia to a new host plant and enable bacteria with a different genomic background but similar nod genes to enter symbiotic interactions with the same legume plants. Some studies of genus Mesorhizobium strains suggest that the broad host range of these bacteria may also be the result of the convergence of distinct nod genotypes into the same nodulation phenotype (Haukka et al. 1998; Wernegreen and Riley 1999). It is worth noting that currently the nodC gene sequence analysis is commonly used for grouping rhizobia into symbiovars (Laguerre et al. 2001; Diouf et al. 2010).

The nodC gene sequence analysis of the $O$. arvensis nodule isolates indicated that four strains, OA4, OA121, OA129, and OA245, are phylogenetically closely related to the species $M$. tarimense and $M$. lot $i$ (98-99\% sequence similarities). The three other isolates from $O$. arvensis nodules, i.e., OA118, OA132, and OA191, as in the 16S rRNA phylogram, grouped with strains of the genus Rhizobium (76-97\% sequence similarity). It is important to emphasize that the nodC gene encoding $\mathrm{N}$-acetylglucosaminyltransferase and determining the length of the chitin oligosaccharide chain of the Nod factor is one of the factors associated 
with the host range (Perret et al. 2000). Interestingly, it was observed that the photosynthetic Bradyrhizobium ORS278 and BTAi1 strains forming symbiosis with Aeschynomene species did not harbour nodABC genes but were still able to establish symbiosis with legume plants. This indicates the existence of independence from Nod factor determinants in rhizobium-legume symbiotic interactions (Wernegreen and Riley 1999; Laguerre et al. 2001; Giraud et al. 2007; Diouf et al. 2010; Okazaki et al. 2016).

All the seven $O$. arvensis microsymbionts studied (OA4, OA118, OA121, OA129, OA132, OA191, and OA245) have been found to possess acdS gene sequences very similar to those of M. loti NZP2213 and Mesorhizobium tarimense CCBAU83306. This might suggest that the OA118, OA132, and OA191 strains, classified to the genus Rhizobium by the $16 \mathrm{~S}$ rRNA gene sequence analysis, have acquired the $a c d S$ gene through horizontal transfer from Mesorhizobium bacteria. The acquisition of the acdS gene by lateral transfer of a symbiotic island has been demonstrated in some Mesorhizobium sp. strains (Nandasena et al. 2007; Glick 2014; Nascimento et al. 2014).

The host range is still an important feature in the description of new species of nodule bacteria (Graham et al. 1991). Up to now, there has been little information available about the host range of $O$. arvensis microsymbionts. Novikova et al. (1993) described five strains isolated from $O$. arvensis root nodules that formed symbiosis also with $L$. corniculatus. The results of our plant tests demonstrated that bacteria specific for $O$. arvensis exhibit a narrow host range and induce effective nitrogen fixing nodules only on the roots of their host plant and $O$. spinosa but not on $T$. repens, $M$. sativa or $L$. corniculatus. The ability of restharrow symbionts to form mutualistic interactions with $O$. spinosa, i.e. a plant which is under partial protection in Poland, can be useful in protecting and promoting the growth of this fabacean.

Fabacean plants, similar as nodule bacteria, differ in their symbiotic specificity and one plant species may interact with many taxonomically different rhizobia species, whereas another one forms symbiosis with unique root nodule bacteria (Ferro et al. 2000; Laranjo et al. 2014). In the plant tests, O. arvensis was effectively nodulated by many Mesorhizobium and Rhizobium species but not by Ensifer, Neorhizobium, and Bradyrhizobium species and therefore, O. arvensis may be determined as a promiscuous host for rhizobia.
Open Access This article is distributed under the terms of the Creative Commons Attribution 4.0 International License (http:// creativecommons.org/licenses/by/4.0/), which permits unrestricted use, distribution, and reproduction in any medium, provided you give appropriate credit to the original author(s) and the source, provide a link to the Creative Commons license, and indicate if changes were made.

\section{References}

Albuquerquea P, Mendesa MV, Santosa CL, Moradas-Ferreira P, Tavaresa F (2009) DNA signature-based approaches for bacterial detection and identification. Sci Total Environ 407:3641-3651

Antoun H, Beauchamp CJ, Goussard N, Chabot R, Lalande R (1998) Potential of Rhizobium and Bradyrhizobium species as plant growth promoting rhizobacteria on non-legumes: effects on radishes (Raphanus sativus L.). Plant Soil 204:57-67

Anwar S, Ali B, Sajid I (2016) Screening of rhizospheric actinomycetes for various in vitro and in vivo plant growth promoting (PGP) traits and for agroactive compounds. Front Microbiol 7:1334. doi:10.3389/fmicb.2016.01334

Ardley JK, Parker MA, de Meyer SE, Trengove RD, O'Hara GW, Reeve WG, Yates RJ, Dilworth MJ et al (2012) Microvirga lupini sp. nov., Microvirga lotononidis sp. nov. and Microvirga zambiensis sp. nov. are alphaproteobacterial root-nodule bacteria that specifically nodulate and fix nitrogen with geographically and taxonomically separate legume hosts. Int J Syst Evol Microbiol 62:2579-2588

Arun AB, Sridhar KR (2005) Growth tolerance of rhizobia isolated from Sand Dune legumes of Southwest coast of India. Eng Life Sci 5:134-138

Badenoch-Jones BG, Rolfe DS, Letham DS (1983) Phytohormones, Rhizobium mutants and nodulation in legumes. Plant Physiol 73:347-352

Boakye EY, Lawson IY, Danso SKA, Offei SK (2016) Characterization and diversity of rhizobia nodulating selected tree legumes in Ghana. Symbiosis 69:89-99. doi:10.1007/ s13199-016-0383-1

Brusetti L, Malkhazova I, Gtari M, Tamagnini I, Borin S, Merabishvili M, Chanishvili N, Mora D et al (2008) Fluorescent-BOX-PCR for resolving bacterial genetic diversity, endemism and biogeography. BMC Microbiol $8: 220-232$

Cubo MT, Buendia-Claveria AM, Beringer JE, Ruiz-Sainzi JE (1988) Melanin production by Rhizobium strains. Appl Environ Microbiol 54:1812-1817

deSouza R, Ambrosini A, Passaglia LMP (2015) Plant growthpromoting bacteria as inoculants in agricultural soils. Genet Mol Biol 38:401-419

Diouf D, Fall D, Chaintreuil C, Ba AT, Dreyfus B, Neyra M, Ndoye I, Moulin L (2010) Phylogenetic analyses of symbiotic genes and characterization of functional traits of Mesorhizobium spp. strains associated with the promiscuous species Acacia seyal Del. J Appl Microbiol 108:818-830

Elboutahiri N, Thami-Alami I, Udupa SM (2010) Phenotypic and genetic diversity in Sinorhizobium meliloti and $S$. 
medicae from drought and salt affected regions of Morocco. BMC Microbiol 10:15

Ferro M, Lorquin J, Ba S, Sanon K, Prome JC, Boivin K (2000) Bradyrhizobium sp. Strains that nodulate the leguminous tree Acacia albida produce fucosylated and partially sulfated Nod factors. Appl Environ Microbiol 66:5078-5082

Gampe N, Darcsi A, Lohner S, Béni S, Kursinszki L (2016) Characterization and identification of isoflavonoid glycosides in the root of spiny restharrow (Ononis spinosa L.) by HPLC-QTOF-MS, HPLC-MS/MS and NMR. J Pharm Biomed Anal 123:74-81

Gillings M, Holley M (1997) Repetitive element PCR fingerprinting (rep-PCR) using enterobacterial repetitive intergenic consensus (ERIC) primers is not necessarily directed at ERIC elements. Lett Appl Microbiol 25:17-21

Giraud E, Moulin L, Vallenet D, Barbe V, Cytryn E, Avarre JC, Jaubert M, Simon D et al (2007) Legumes symbioses: absence of Nod genes in photosynthetic bradyrhizobia. Science 316:1307-1312

Glick BR (2014) Bacteria with ACC deaminase can promote plant growth and help to feed the world. Microbiol Res 169:30-39

Gnat S, Wójcik M, Wdowiak-Wróbel Kalita M, Ptaszyńska A, Małek W (2014) Phenotypic characterization of Astragalus glycyphyllos symbionts and their phylogeny based on the 16S rDNA sequences and RFLP of $16 \mathrm{~S}$ rRNA gene. Ant van Leeuwen 105:1033-1048. doi:10.1007/s10482-0140163-y

Gnat S, Małek W, Oleńska E, Wdowiak-Wróbel S, Kalita M, Łotocka B, Wójcik M (2015) Phylogeny of symbiotic genes and the symbiotic properties of rhizobia specific to Astragalus glycyphyllos L. PLoS ONE 10(10):e0141504. doi:10.1371/journal.pone.0141504

Gopalakrishnan S, Sathya A, Vijayabharathi R, Varshney RK, Gowda CLL, Krishnamurthy L (2015) Plant growth promoting rhizobia: challenges and opportunities. 3. Biotech 5:355-377. doi:10.1007/s13205-014-0241-x

Graham PH, Vance CP (2003) Legumes: importance and constraints to greater use. Plant Physiol 131:872-877

Graham PH, Sadowsky MJ, Keyser HH, Barnet YM, Bradley RS, Cooper JE, De Ley J, Jarvis BDW et al (1991) Proposed minimal standards for the description of new genera and species of root- and stem-nodulating bacteria. Int J Syst Bacteriol 41:582-587

Greenwood DJ (1982) Nitrogen supply and crop yield: the global scene. Plant Soil 67:45-59

Guerinot ML, Meidl EJ, Plessner O (1990) Citrate as a siderophore in Bradyrhizobium japonicum. J Bacteriol 172(3298):3303

Gupta M, Kiran S, Gulati A, Singh B, Tewari R (2012) Isolation and identification of phosphate solubilizing bacteria able to enhance the growth and aloin-A biosynthesis of Aloe barbadensis Miller. Microbiol Res 167:358-363

Han TX, Han LL, Wu LJ, Chen WF, Sui XH, Gu JG, Wang ET, Chen WX (2008) Mesorhizobium gobiense sp. nov. and Mesorhizobium tarimense sp. nov., isolated from wild legumes growing in desert soils of Xinjiang, China. Int J Syst Evol Microbiol 58:2610-2618

Hao Y, Charles TC, Glick BR (2011) An ACC deaminase containing A. tumefaciens strain D3 shows biocontrol activity to crown gall disease. Can J Microbiol 57:278-286
Hassan W, Hussain M, Bashir S, Shah AN, Bano R, David J (2015) ACC-deaminase and/or nitrogen fixing rhizobacteria and growth of wheat (Triticum Aestivum L.). J Soil Sci Plant Nutr 15:232-248

Haukka K, Lindstrom KM, Young PJW (1998) Three phylogenetic groups of nodA and nifH genes in Sinorhizobium and Mesorhizobium isolates from leguminous trees growing in Africa and Latin America. Appl Environ Microbiol 64:419-426

Hofer AW (1941) A characterization of Bacterium radiobacter (Beijerinck and Van Delden) Lohnis. J Bacteriol 41:193-224

Jarvis BDW, Pankhurst CE, Patel JJ (1982) Rhizobium loti, a new species of legume root nodule bacteria. Int J Syst Bacteriol 32:378-380

Jarvis BDW, van Berkum P, Chen WX, Nour SM, Fernandez MP, Cleyet-Marel JC, Gillis M (1997) Transfer of Rhizobium loti, Rhizobium huakuii, Rhizobium ciceri, Rhizobium mediterraneum, and Rhizobium tianshanense to Mesorhizobium gen. nov. Int J Syst Bacteriol 47:895-898

Kimura M (1980) A simple method for estimating evolutionary rates of base substitutions through comparative studies of nucleotide sequences. J Mol Evol 16:111-120

Kirmizigul S, Goren N, Yang SW, Cordell GA, Bozok-Johansson C (1997) Spinonin, a novel glycoside from Ononis spinosa subsp. leiosperma. J Nat Prod 60:378-381

Laguerre G, Nour SM, Macheret V, Sanjuan J, Drouin P, Amarger NI (2001) Classification of rhizobia based on nodC and nifH gene analysis reveals a close phylogenetic relationship among Phaseolus vulgaris symbionts. Microbiol 147:981-993

Laranjo M, Alexandre A, Oliveira S (2014) Legume growthpromoting rhizobia: an overview on the Mesorhizobium genus? Microbiol Res 169:2-17

Larkin MA, Blackshields G, Brown NP, Chenna R, McGettigan PA, McWilliam H, Valentin F, Wallace IM et al (2007) ClustalW and ClustalX version 2.0. Bioinformatics 23:2947-2948

Louden BC, Haarmann D, Lynne AM (2011) Use of blue agar CAS assay for siderophore detection. J Microbiol Biol Educ 12:51-53

Louws FJ, Fulbright DW, Stephens CT, de Bruijn FJ (1994) Specific genomic fingerprints of phytopathogenic Xanthomonas and Pseudomonas pathovars and strains generated with repetitive sequences and PCR. Appl Environ Microbiol 60:2286-2295

Ma W, Sebestianova SB, Sebestian J, Burd GI, Guinel FC, Glick BR (2003) Prevalence of 1-aminocyclopropane-1-carboxylate deaminase in Rhizobium spp. Ant van Leeuwen 83:285-291

Mathesius U, Schlaman HRM, Spaink HP, Sautter C, Rolfe BG, Djordjevic MA (1998) Auxin transport inhibition precedes root nodule formation in white clover roots and is regulated by flavonoids and derivatives of chitin oligosaccharides. Plant J 14:23-34

Nagarajkumar M, Bhaskaran R, Velazhahan R (2004) Involvement of secondary metabolites and extracellular lytic enzymes produced by Pseudomonas fluorescens in inhibition of Rhizoctonia solani, the rice sheath blight pathogen. Microbiol Res 159:73-81

Nandasena KG, O’Hara GW, Tiwari RP, Sezmiş E, Howieson JG (2007) In situ lateral transfer of symbiosis islands 
results in rapid evolution of diverse competitive strains of mesorhizobia suboptimal in symbiotic nitrogen fixation on the pasture legume Biserrula pelecinus L. Environ Microbiol 9:2496-2511

Nascimento FX, Rossi MJ, Soares CRFS, McConkey BJ, Glick BR (2014) New insights into 1-aminocyclopropane-1carboxylate (ACC) deaminase phylogeny, evolution and ecological significance. PLoS ONE 9:e99168

Nei M, Li WH (1979) Mathematical model for studying genetic variation in terms of restriction endonucleases. Proc Natl Acad Sci 76:5269-5273

Niemann S, Pühler A, Tichy HV, Simon R, Selbitschka W (1997) Evaluation of the resolving power of three different DNA fingerprinting methods to discriminate among isolates of a natural Rhizobium meliloti population. J Appl Microbiol 82:477-484

Nour SM, Fernandez MP, Normand P, Cleyet-Marel JC (1994) Rhizobium ciceri sp. nov., consisting of strains that nodulate chickpeas (Cicer arietinum L.). Int J Syst Bacteriol 44:511-522

Novikova NI, Pavlova EA, Limeshchenko EV (1993) Phage sensitivity and host range of Rhizobium strains isolated from root nodules of temperate legumes. Plant Soil 151:45-53

Okazaki S, Tittabutr P, Teulet A, Thouin J, Fardoux J, Chaintreuil C, Gully D, Arrighi JF et al (2016) Rhizobiumlegume symbiosis in the absence of Nod factors: two possible scenarios with or without the T3SS. ISME J 10:64-74

Peix A, Ramırez-Bahena MH, Velazquez E, Bedmar EJ (2015) Bacterial associations with legumes. Crit Rev Plant Sci 34:17-42

Perret X, Staehelin C, Broughton WJ (2000) Molecular basis of symbiotic promiscuity. Microbiol Mol Biol Rev 64:180-201

Pitcher DG, Saunders NA, Owen RJ (1989) Rapid extraction of bacterial genomic DNA with guanidium thiocyanate. Lett Appl Microbiol 8:151-156

Rademaker JLW, Hoste B, Louws FJ, Kersters K, Swings J, Vauterin L, Vauterin P, de Bruijn FJ (2000) Comparison of AFLP and rep-PCR genomic fingerprinting with DNADNA homology studies: Xanthomonas as a model system. Int J Syst Evol Microbiol 50:665-677

Rajendhran J, Gunasekaran P (2011) Microbial phylogeny and diversity: small subunit ribosomal RNA sequence analysis and beyond. Microbiol Res 166:99-110

Ramírez-Bahena MH, García-Fraile P, Peix A, Valverde A, Rivas R, Igual JM, Mateos PF, Martinez-Molina E et al (2008) Revision of the taxonomic status of the species Rhizobium leguminosarum (Frank 1879) Frank 1889AL, Rhizobium phaseoli Dangeard 1926AL, and Rhizobium trifolii Dangeard 1926AL. R. trifolii is a later synonym of $R$. leguminosarum. Reclassification of the strain R. leguminosarum DSM 30132 (= NCIMB 11478) as Rhizobium pisi sp. nov. Int J Syst Evol Microbiol 58:2484-2490

Raychaudhuri N, Das SK, Chakrabartty PK (2005) Symbiotic effectiveness of a siderophore overproducing mutant of Mesorhizobium ciceri. Pol J Microbiol 54:37-41

Reigh G, O'Connell M (1993) Siderophore-mediated iron transport correlates with the presence of specific iron regulated proteins in the outer membrane of Rhizobium meliloti. J Bacteriol 175:94-102
Rincón A, Arenal F, González I, Manrique E, Lucas MM, Pueyo JJ (2008) Diversity of rhizobial bacteria isolated from nodules of the Gypsophyte Ononis tridentata L. growing in Spanish soils. Microb Ecol 56:223-233

Rosselló-Mora R, Amann R (2001) The species concept for prokaryotes. FEMS Microbiol Rev 25:39-67

Sherwood MT (1970) Improved synthetic medium for the growth of Rhizobium. J Appl Bacteriol 33:708-713

Spaepen S, Vanderleyden J (2011) Auxin and plant-microbe interactions. Cold Spring Harb Perspect Biol 3(4):a001438

Suntar I, Baldemir A, Coskun M, Keles H, Akkol EK (2011) Wound healing acceleration effect of endemic Ononis species growing in Turkey. J Ethnopharmacol 135:63-70

Tamura K, Dudley J, Nei M, Kumar S (2007) MEGA4: Molecular Evolutionary Genetics Analysis (MEGA) Software Version 4.0. Mol Biol Evol 24:1596-1599

Thies JE, Holmes EM, Vachot A (2001) Application of molecular techniques to studies in Rhizobium ecology: a review. Aust J Exp Agric 41:299-319

Tian CF, Wang ET, Wu LJ, Han TX, Chen WF, Gu CT, Gu JG, Chen WX (2008) Rhizobium fabae sp. nov., a bacterium that nodulates Vicia faba. Int J Syst Evol Microbiol 58:2871-2875

Vandamme P, Pot B, Gillis M, de Vos P, Kersters K, Swing J (1996) Polyphasic taxonomy, a consensus approach to bacterial systematics. Microbiol Rev 60:407-438

Wang FQ, Wang ET, Liu J, Chen Q, Sui XH, Chen WF, Chen WX (2007) Mesorhizobium albiziae sp. nov., a novel bacterium that nodulates Albizia kalkora in a subtropical region of China. Int J Syst Evol Microbiol 57:1192-1199

Wani PA, Khan MS, Zaidi A (2008) Effect of metal-tolerant plant growth-promoting rhizobium on the performance of pea grown in metal-amended soil. Arch Environ Contam Toxicol 55:33-42

Wdowiak-Wrobel S, Małek W (2000) Numerical analysis of Astragalus cicer microsymbionts. Curr Microbiol 41:142-148

Wdowiak-Wrobel S, Małek W (2016) Properties of Astragalus sp. microsymbionts and their putative role in plant growth promotion. Arch Microbiol 198:793-801

Wei GH, Wang ET, Tan ZY, Zhu ME, Chen WX (2002) Rhizobium indigoferae sp. nov. and Sinorhizobium kummerowiae sp. nov., respectively isolated from Indigofera spp. and Kummerowia stipulacea. Int J Syst Evol Microbiol 52:2231-2239

Weir BS, Turner SJ, Silvester WB, Park DC, Young JM (2004) Unexpectedly diverse Mesorhizobium strains and Rhizobium leguminosarum nodulate native legume genera of New Zealand, while introduced legume weeds are nodulated by Bradyrhizobium Species. Appl Environ Microbiol 70:5980-5987

Weisburg WG, Barns SM, Pelletier DA, Lane DJ (1991) 16S ribosomal DNA amplification for phylogenetic study. J Bacteriol 173(697):703

Wernegreen JJ, Riley MA (1999) Comparison of the evolutionary dynamics of symbiotic and housekeeping loci: a case for the genetic coherence of rhizobial lineages. Mol Biol Evol 16:98-113

Young JPW, Haukka K (1996) Diversity and phylogeny of rhizobia. New Phytol 133:87-94 